\title{
NEODESENVOLVIMENTISMO, DEGRADAÇÃO DO TRABALHO EM FRIGORÍFICOS E SINDICATOS
}

\author{
NEO-DEVELOPMENTISM, DETERIORATION IN WORK MEAT \\ FRIGORIFICATION SECTOR E LABOR UNIONS
}

\author{
Fernando Mendonça Heck ${ }^{1}$
}

\section{RESUMO}

Há um debate importante que atinge vários campos do conhecimento sobre o chamado neodesenvolvimentismo. As concepções são também variadas que vão desde as críticas radicais, moderadas até a total aceitação de tais teses. Inserimo-nos na primeira perspectiva, por entender que não há rupturas e nem mesmo reformas estruturais que possam conferir ao neodesenvolvimentismo $o$ status de governo de resistência ao neoliberalismo como promulgam seus defensores. Percebemos que o incentivo do Estado ao setor de frigorificação de carnes não é nada desprezível. A geração de empregos particularmente na região Oeste do estado do Paraná teve um salto significativo para esse setor da economia nos últimos 10 anos. No entanto, antes de qualquer comemoração com as cifras estatísticas de crescimento do emprego, observase que o investimento do Estado se dá num dos setores que mais gera acidentes e doenças relacionadas ao trabalho e, por isso, resulta em déficit aos cofres públicos. Os sindicatos, distantes da realidade dos trabalhadores, não conseguem oferecer resistências significativas ao capital e quando muito limitam-se à postura negocial impedindo ações contundentes dos trabalhadores, que se dão à revelia das próprias instituições sindicais. Mostrar - neodesenvolvimentismo enquanto estratégia de hegemonia do capital focando o caso da expansão territorial avícola é o nosso objetivo nesse artigo.

Palavras-chave: Território - Neodesenvolvimentismo - Trabalho.

\section{ABSTRACT}

Neo-developmentism is an important debate that reaches several knowledge fields.. Varied are the conceptions ranging since radical critiques, moderate to full acceptance of such theses. Into the first perspective we understand there are no ruptures and not even structural reforms which may confer to neodevelopmentism the resistance government status to neoliberalism as promulgate their advocates. State incentive to the meat frigorification sector is nothing negligible. An increase of jobs creation in this sector of economy occurred in the western of Parana state in the last 10 years. However, before any celebration with the statistics figures of employment growth it is observed 
the State's investment occurs in one of the sectors that more generates accidents and diseases related to work and e results in deficit to public coffers. The labor unions are distant from workers' reality, and fail to offer significant resistance to capital. At best they are limited to negotiating posture impeding forceful actions of workers which occur behind the backs of their own labor union institutions. Show the neo-developmentism as capital hegemonic's strategy focusing poultry territorial expansion's case is our main goal in this article.

Keywords: territory - neo-developmentism - labor

\section{INTRODUÇÃO}

No contexto do chamado "novo desenvolvimentismo" brasileiro a atividade avícola tem recebido forte estímulo do Estado o que se expressa na sua expansão territorial pelo Brasil. Desde 2007, o Banco Nacional de Desenvolvimento Econômico e Social (BNDES) injetou nas grandes empresas frigoríficas cerca de 13 bilhões de reais (SOARES, 2014), o que significou uma expansão de tais corporações no âmbito do território nacional.

Estes incentivos estatais têm financiado setores, que mesmo do ponto de vista do capital, são os maiores depredadores dos recursos naturais e que processam os produtos de menores valores agregados, sendo ainda hegemonizados pela lógica do capital financeiro. Há então, do ponto de vista capitalista, uma regressão no dinamismo industrial e reforço ao agronegócio (BRANDÃO, 2010).

O capital avícola, processador de produtos de baixo valor agregado, é um dos exemplos fundamentais da política econômica neodesenvolvimentista onde aceita-se a especialização regressiva, o que significa, um recuo imposto pelo modelo capitalista neoliberal aos países dependentes que haviam logrado desenvolver um parque industrial mais complexo (BOITO JUNIOR, 2012).

O Oeste Paranaense nesse contexto tem apresentado uma expansão territorial do capital avícola significativa com um crescimento no número de empregos de mais de 350\% nos últimos dez anos (2000-2010). Contudo, o estímulo a tais atividades tem apresentado aos trabalhadores um emprego 
degradante que atinge a sua saúde em virtude dos inúmeros movimentos repetitivos exigidos nas linhas de desmontagem de frangos.

Mesmo assim, a ação sindical pouco tem se pautado em ações contundentes de enfrentamento ao capital, pelo contrário, além de realçar o suposto desenvolvimento regional promovido pela expansão do capital avícola, tem agido em alguns casos, como em paralisação recente dos trabalhadores num frigorífico no município de Cafelândia, na contramão dos interesses dos trabalhadores com o intuito de fazê-los retornar ao trabalho. Entender e problematizar estes assuntos são o nosso objetivo neste artigo.

\section{NEODESENVOLVIMENTISMO UMA ARMADILHA PARA A CLASSE TRABALHADORA}

Defensores do status quo do pacto de governabilidade petista são os formuladores de uma aposta complicada para o conjunto da classe trabalhadora: o neodesenvolvimentismo. Seus argumentos, geralmente, expressam uma versão exagerada das melhorias que os governos "pósneoliberais", como eles costumam designar, trouxeram para a população empobrecida do Brasil.

Políticas assistencialistas, redução do desemprego e aumento do salário mínimo se tornam os acontecimentos que conceberiam um novo padrão de desenvolvimento para além do neoliberalismo colocando o país na contramão das tendências mundiais caracterizando um governo de resistência (SADER, 2013).

Esse exagero em considerar tais governos pelo viés de rupturas radicais com a década neoliberal é bastante problemático e tem favorecido leituras pobres e excessivas, no caso brasileiro, sobre as transformações ocorridas nos 12 anos de comando petista.

É óbvio, que houve alguns avanços na política social, como os próprios indicadores sugerem, mas, a burguesia nacional é quem mais tem ganhado com o governo "pós-neoliberal" do petismo no Brasil. Por isso, não estamos vivendo nenhuma ruptura radical como pressupõem os defensores mais entusiasmados dos 12 anos de governo PT no Brasil. 
Longe de ultrapassar este último, o neodesenvolvimentismo é apenas um simulacro do antigo desenvolvimentismo (SAMPAIO JUNIOR, 2012). As suas transformações de ordem social não tocam em questões fundamentais como a manutenção da estrutura arcaica da posse da terra no Brasil. Aqui reside uma diferença fundamental entre os "antigos" desenvolvimentistas (1930-1980) e os neodesenvolvimentistas. Os primeiros defendiam as chamadas reformas estruturais enquanto que os segundos estão longe disso. E, não é mero acidente conjuntural como querem nos fazer crer os avalistas governistas $^{2}$. Ao contrário, foi uma aposta do pacto de governabilidade petista e que não têm o objetivo nem de longo prazo de produzir reformas estruturais que incomodem a burguesia brasileira. Então, é ilusão esperar que do petismo advenha reformas estruturais, como a reforma agrária, por exemplo, o que expõe os limites do neodesenvolvimentismo e mostra a sua tendência de não promover modificações que toquem no poderio, principalmente, da burguesia agrário-exportadora.

É por isso que o agronegócio tanto têm se expandido no território nacional mantendo a concentração da terra e a reforma agrária não tenha avançado nos oito anos de Lula e nos 4 anos de Dilma.

O campesinato pobre, que corresponde aos camponeses sem-terra ou com pouca terra, reivindica a desapropriação das terras ociosas e uma política agressiva de abertura de novos assentamentos. Essa camada camponesa é a mais marginalizada pela frente neodesenvolvimentista. Os governos Lula e Dilma reduziram muito as desapropriações de terra (BOITO JUNIOR e BERRINGER, 2013, p.33).

Aliás, o incentivo aos setores arcaicos da economia como o agronegócio mostra uma diferença fundamental entre os desenvolvimentistas e o simulacro atual, já que os primeiros defenderam o desenvolvimento da indústria nacional dos setores mais sofisticados como indústrias de base, bens de consumo durável, bens de capital, indústria aeronáutica, informática, bélica e outros (BOITO JUNIOR, 2012).

No modelo neodesenvolvimentista, as grandes empresas nacionais, classificadas entre as empresas mais fortes dos seus respectivos segmentos em escala mundial, são - feita a exceção de praxe representada pela Embraer - a Friboi, a Brasil Foods, a Vale, a 
Gerdau, a Votorantim Celulose e outras que processam produtos de baixo valor agregado (BOITO JUNIOR, 2012, p.70).

Aqui vale um esclarecimento. Não estamos defendendo as teses desenvolvimentistas. Pelo contrário, não acreditamos em teses que propugnam um capitalismo mais humano, estas estão fracassadas, como a decadência do welfare state é prova fundamental. Nesse ponto estamos com Mészárós (2007) quando afirma que o capital é irreformável e a alternativa para esse é a ruptura radical com o sociometabolismo do capital.

Apenas estamos expondo as diferenças entre o período atual e as propostas desenvolvimentistas do passado, bem como, colocando contraponto ao próprio período neoliberal.

Com este último, é possível perceber diferenças entre os governos do Partido dos Trabalhadores (PT) e de Fernando Henrique Cardoso (PSDB). De fato, a política social é algo que nos permite diferenciar estes governos. Os indicadores sociais melhoraram no período Lula-Dilma, mas, mesmo assim, preservou-se os pilares do neoliberalismo no Brasil (ALVES, 2013). Então, não há nenhuma "mudança radical” em curso.

Em decorrência disso, é possível perceber que os apologetas acríticos do governismo atual, exageram - muitas vezes por paixão partidária nas transformações que aconteceram no Brasil. Não estamos a caminho de nenhuma reforma estrutural com os governos petistas. Ao contrário, a burguesia nacional tem ido muito bem. Assim, como disse o próprio Lula, os usineiros são "heróis da nação", o que discursivamente representa o protagonismo que o agronegócio assumiu na política de Estado em detrimento das reformas estruturais como a reforma agrária.

$\mathrm{E}$, de fato não a temos. Os 12 anos de petismo mostraram que a política econômica realçou os setores mais arcaicos da economia (agronegócio), restando aos trabalhadores às reformas fracas ${ }^{3}$, cujo, objetivo é distribuir a renda sem tocar em nenhuma reforma estrutural que incomode a burguesia nacional.

Nesse sentido, o neodesenvolvimentismo não é uma alternativa para os trabalhadores. Muito menos ao neoliberalismo. É uma falácia, em termos de transformações sociais efetivas, mesmo que tenha melhorado os indicadores sociais - o que diferencia este do período neoliberal de FHC. 
Aos que argumentam que o neodesenvolvimentismo é bom tanto para a burguesia quanto para os trabalhadores alguns indicadores desmistificam tal logro: o orçamento que o BNDES destina para um número reduzido de grandes empresas é cerca de sete vezes maior que o orçamento destinado para o Bolsa Família que se dedica a 45 milhões de brasileiros em situação de pobreza (BOITO JUNIOR e BERRINGER, 2013).

É a lógica do capital que se reproduz pela via estatal: Estado mínimo para os trabalhadores e máximo para o capital. Continua sendo assim, mesmo com os ajustes das políticas sociais.

Não obstante, no que tange a divisão internacional do trabalho o Brasil tem tido papel central para o fornecimento de commodities minerais e agrícolas. A atividade de processamento de carnes tem recebido grandes investimentos por parte do Estado, principalmente às grandes empresas brasileiras (JBS, Marfrig e Brasil Foods), via BNDES.

O estímulo a tais capitais que processam produtos de baixo valor agregado, nunca é demais lembrar, mesmo do ponto de vista da economia capitalista representam retrocessos. Regride-se o já débil dinamismo industrial fortalecendo ainda mais a concentração de renda e da propriedade da terra, lógica que cria hordas de despossuídos, de desabilitados pela propriedade e, de outro lado, uma elite mercantil rentista arraigada em imensas porções de terra (BRANDÃO, 2010).

Por conseguinte, o Estado apóia empresas que geram déficits para a Previdência Social tendo em vista o alto grau de doenças laborais como o setor frigorífico. Para ficarmos com um único exemplo: somente a Brasil Foods entre os anos de 2003-2007 gerou uma despesa de 100 milhões de reais aos cofres públicos da Previdência Social em benefícios que a autarquia teve de pagar aos trabalhadores lesionados dessa companhia (NOTICIAS, PRT-RS, 2009).

Portanto, o neodesenvolvimentismo é uma armadilha para a classe trabalhadora, já que ao mesmo tempo em que representa pequenos ganhos em termos, principalmente, de políticas assistenciais, é um Estado máximo para a burguesia nacional a mesma que impõe péssimas condições de trabalho atingindo até mesmo a saúde dos trabalhadores. Eis, o ardil da conjuntura atual, que deve nos guiar para uma reflexão crítica a qual não determine por dentro dos limites da ordem burguesa, a solução para os problemas sociais. 


\section{EXPANSÃO TERRITORIAL DO CAPITAL AVÍCOLA, DEGRADAÇÃO DO TRABALHO E OS SINDICATOS}

Nessa conjuntura, a aposta do governo no setor frigorífico é evidente. É o Estado máximo para o capital que nesse caso é o mesmo que gera déficits significativos para a Previdência Social com as doenças do trabalho (conseqüências negativas para a classe trabalhadora).

A participação do Estado na expansão e consolidação do agronegócio frigorífico no Oeste Paranaense tem sido fundamental, já que entre 2004 e 2007, mais de 1 bilhão de reais foram injetados pelo mesmo nas cooperativas do Oeste Paranaense principalmente para a cadeia de abate de frangos/suínos ${ }^{4}$. Isso sem falar da Brasil Foods localizada também na região e que tem ganhado forte estímulo do BNDES como os 2,5 bilhões solicitados em 2012.

Portanto, pode-se perceber que há uma correlação entre os investimentos do Estado nos frigoríficos da região e a expansão do emprego fabril entre 2000-2010 na marca de um crescimento de mais de 350\% (Gráfico 1). A expansão territorial do capital frigorífico torna-se evidente demonstrando a construção da hegemonia do agronegócio no Oeste Paranaense fortemente apoiada pelo Estado.

Gráfico 1 - Evolução do emprego formal em frigoríficos de aves e suínos Oeste do Paraná (1994-2011)

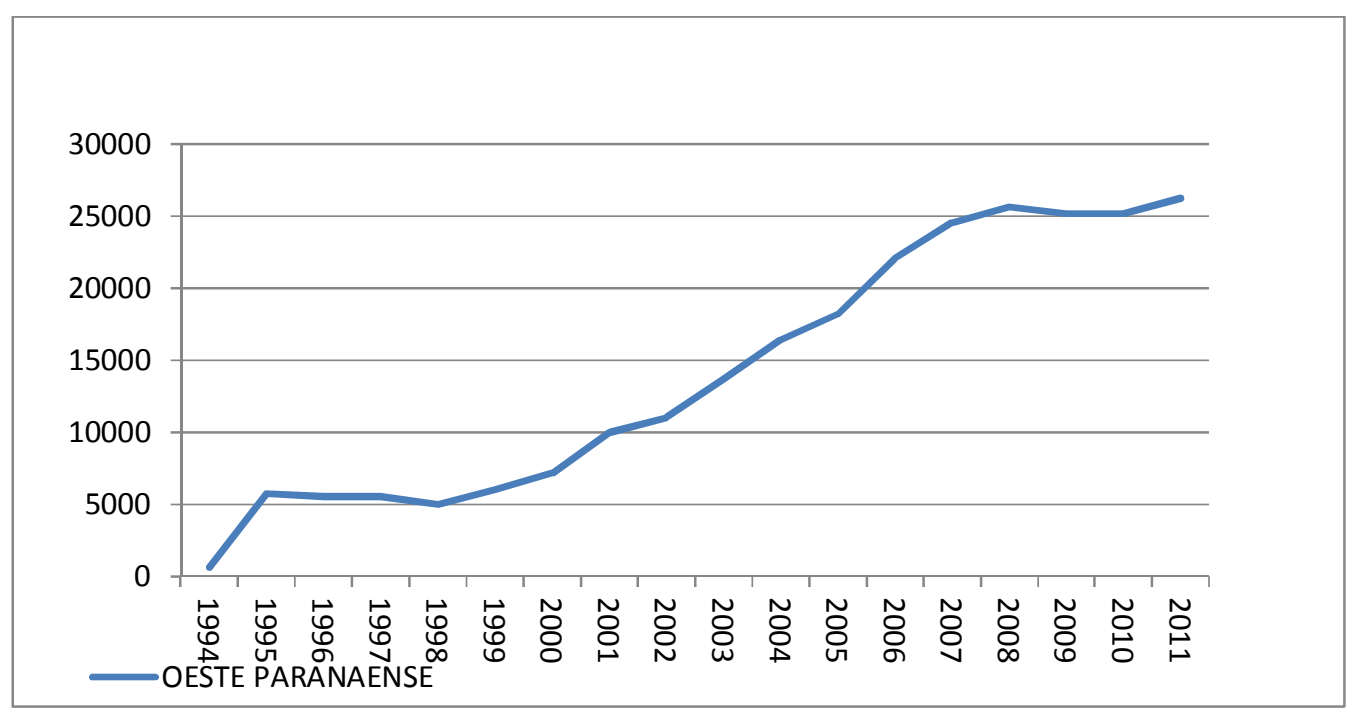

Fonte: MTE/RAIS. 
A distribuição espacial do emprego fabril em frigoríficos processadores de carnes de aves e de suínos no estado do Paraná sofre alterações entre 1994 e $2011^{5}$ (Figura 1 e 2). A concentração de postos de trabalho na atividade no Oeste do Paraná em 2011 representa a consolidação da região como a principal empregadora na atividade reunindo praticamente a metade do emprego disponível no estado para o setor frigorífico (Figura 1 e 2).

Nesse sentido, a expansão territorial do capital se consolida estimulada pelas políticas de Estado via destinação dos recursos do BNDES. Repetimos um Estado máximo para o capital e que financia sua expansão geográfica nos lugares. Hegemoniza o território com o projeto do agronegócio, mas, ao mesmo tempo, cria suas contradições.

Já tocamos no déficit gerado somente pela Brasil Foods aos cofres públicos da Previdência Social. Agora, foquemos nos sujeitos e nas condições de trabalho vivenciadas por eles nos abatedouros de carne avícola-suína. Joana ${ }^{6}$ demonstra como são as condições de trabalho exigidas em tais indústrias:

Você não agüenta os braços você tem que ter força, e daí eu caí, uma loucura. Daí depois você vai lá põe aqueles lá assim aí cabem lá numa máquina de lingüiça lá e cabe mais (...) põe a tripa lá e a lingüiça ta saindo e você tem que ser rápida tem que pegar aqueles lá assim e ficar colocando e depois pesando que nem uma louca (...) (Joana, informação verbal).

E, Roberto complementa ressaltando as doenças laborais resultantes das condições de trabalho:

(...) aí me colocaram numa linha de desossa, parte de desossa de perna de frango. Nós começamos a desossar frango, perna de frango, com 28 segundos, 28 segundos por perna e daí passando uma semana daí veio de 28 caiu para 26 , aí foi passando os meses aí diminuindo pra 25 aí de 25 foi diminuindo, veio diminuindo pra (...) de 25 pra 23 de 23 pra 20 e pra 18 aí veio diminuindo aí chegou até de 18 veio pra (...) quando eu vi que eu não agüentava trabalhar mais aí comecei a pegar ficha ${ }^{7}$, ficha, ficha, vi que eu não agüentei mais daí eu encostei $i^{8}$ (...) no último e tal eu tava fazendo desossa com 15 segundos desossando uma perna a cada 15 segundos, uma perna pra exportação, então dali pra cá foi ali que eu encostei né (...) (Roberto, informação verbal). 
Figura 1 - Emprego formal em frigoríficos de aves e suínos regiões do Paraná 1994

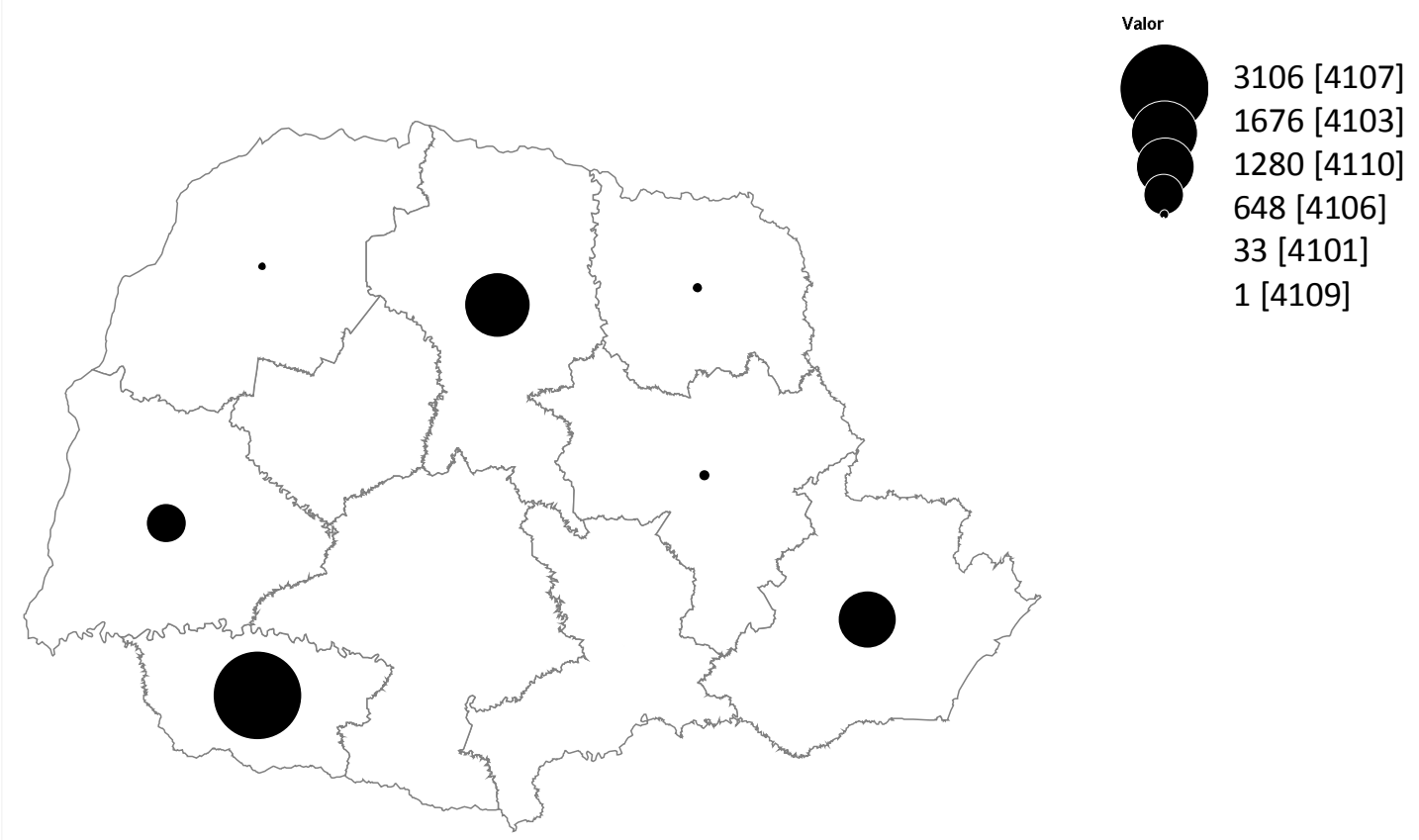

Fonte: MTE/RAIS - adaptada.

Elaborado com Philcarto * 13/01/2014 21:33:56 " hitp://philcarto free fr

Figura 2 - Emprego formal em frigoríficos de aves e suínos regiões do Paraná 2011

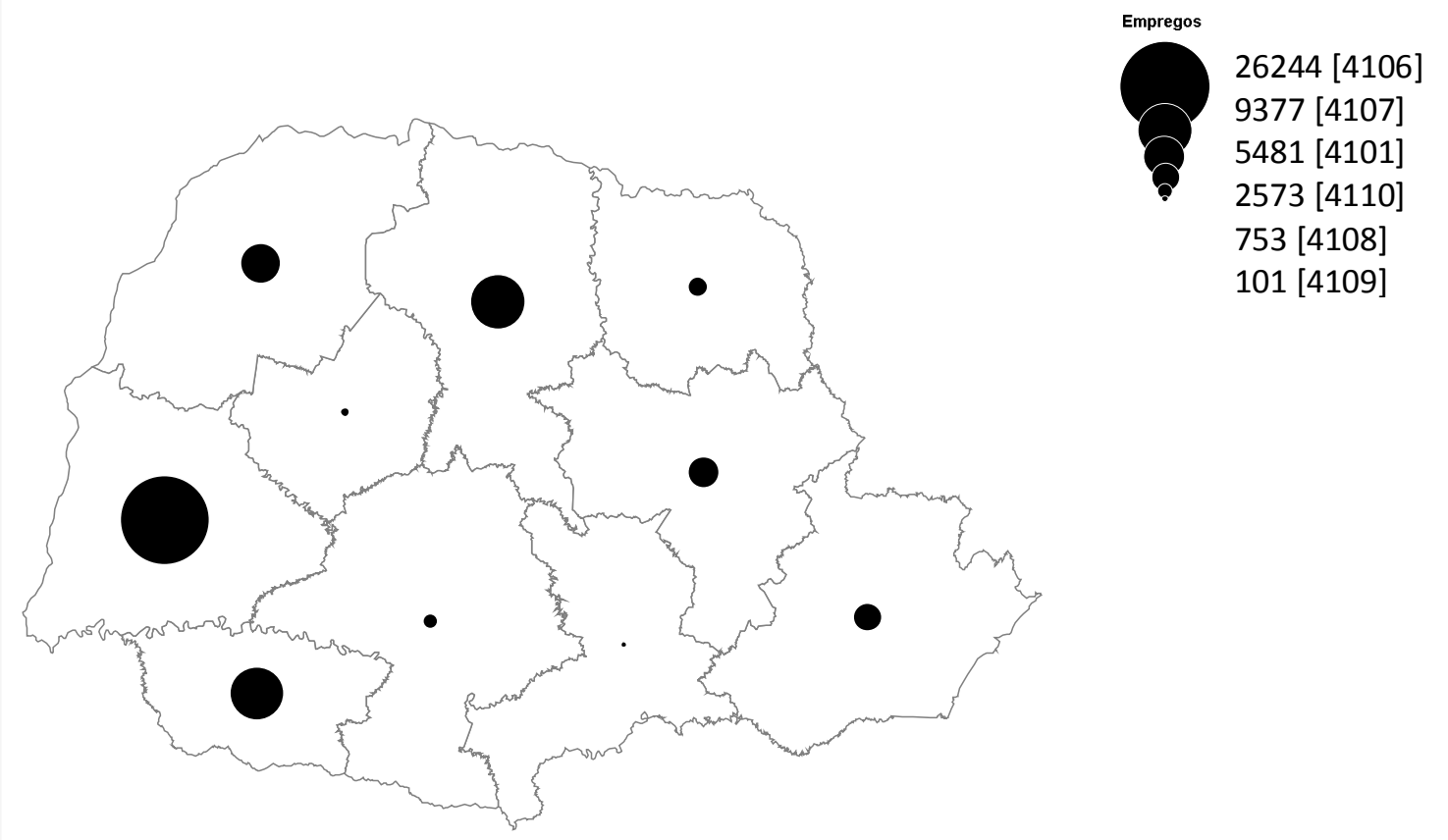

Fonte: MTE/RAIS.

Elaborado com Philcarto = 14/01/2014 11:51:53 * http://philcarto.free.fr 
Esses testemunhos do mundo do trabalho apontam para a materialização da degradação do trabalho nos frigoríficos. O Ministério Público do Trabalho (MPT) também denuncia constantemente irregularidades no setor frigorífico e mostra que em investigações no Oeste do Paraná constatou-se vários afastamentos de trabalhadores por doença ocupacional, além de lesões decorrentes de esforços repetitivos, postos de trabalho inadequados, ausência de intervalos em setores com exposição às baixas temperaturas e pausas insuficientes $^{9}$ (INFORMATIVO PRT9, 2009; 2011).

E ainda mais, conforme a Ação Civil Pública movida contra a Brasil Foods de Toledo (PR), o argumento dos procuradores é de que existe a relação entre as condições de trabalho e os agravos físicos e mentais sofridos pelos trabalhadores ${ }^{10}$.

No entanto, os sindicatos, mesmo que tenham conhecimento das condições de trabalho impostas, assumem posturas de ação política de colaboração de classes, evitando o conflito. Aliás, manter essa atitude defensiva parece ter sido decisiva para o "respeito" por parte de uma das cooperativas regionais ao aceitar a presença do sindicato no cotidiano da empresa:

(...) hoje as coisas melhorou muito a nossa relação melhorou, começaram a abrir para nós visitar o frigorífico. Agora esse ano (2014) até agora a gente não fez visita em frigorífico de cooperativa porque não tinha abertura pra entrar. Não, sindicato não pode entrar dentro de cooperativa. O nosso trabalho era feito ali. Uma vez fomos fazer um trabalho em frente a cooperativa e até tinha uma faixa onde os caminhões paravam nós não podíamos passar daquela faixa nós tínhamos que ficar da faixa, se o presidente chegasse nós atravessasse a faixa a briga estava feita entendeu? Então era muito radical, hoje não. Hoje, quer dizer, o gerente ele foi trabalhando e foi mostrando que o sindicato não é isso que, está aí para fazer não está pra baderna não está pra isso e aquilo, mas, apenas quer ajudar. Porque se eles dão abertura pra nós poder ajudar a cooperativa nós vamos ajudar nós não vamos querer né arrebentar a cooperativa a questão nossa é ajudar se a cooperativa puder crescer 100 por cento e gerar mais emprego pra nós é melhor né? (Representante sindical, informação verbal, grifo nosso).

Ou seja, quando o sindicato se mostrou como uma força de colaboração com o projeto da empresa, obteve o respeito da mesma. Por isso, participa ativamente na postura negocial. Outro representante sindical chega mesmo a nos narrar essa opção política dos sindicatos de trabalhadores em 
cooperativas: “(...) eu sou sindicato, não para denunciar, eu sou sindicato para negociar" (Representante sindical, informação verbal).

Ambos avessos ao radicalismo da ação sindical que paute o embate entre as classes demonstram através das suas narrativas, o projeto do movimento sindical de trabalhadores em cooperativas no Oeste Paranaense: a negação do conflito de classe e a busca pela colaboração de classes entre capital e trabalho - o que corrobora com as avaliações de Varussa (2012) e Bosi (2012) sobre a ação sindical na região.

E tal atuação, para as lideranças entrevistadas, significa o diálogo junto às empresas com 0 objetivo de resolver os problemas. Consequentemente, os mesmos não negam a existência das doenças do trabalho nos frigoríficos e até as assumem como a grande problemática a ser enfrentada, mas, acreditam na resolução desse problema por ações pontuais no próprio ambiente de trabalho. Isso significa que os sindicatos não se enxergam necessariamente no pólo oposto do capital, no conflito de classes, pelo contrário, se lêem enquanto parte do projeto do capital, do qual, através da negociação podem encontrar 0 ambiente ideal, para obterem maiores aumentos salariais, ao conjunto dos trabalhadores, e, resolver os problemas das condições de trabalho.

Portanto, as doenças do trabalho não são assumidas pelos mesmos como produtos da lógica do lucro a qualquer custo. Nem mesmo a crítica ao capitalismo faz parte do discurso desses sindicalistas. Por isso, as doenças, na visão dos últimos, podem ser resolvidas ou amenizadas, pela ação pontual como a modificação de um posto de trabalho, mecanização de determinadas funções e implementação da lei como a Normativa Regulamentadora 36 (NR36).

A luta resume-se ao contingente, negociado e ao diálogo entre capital e trabalho. $E$ até mesmo assume-se que não se deve negociar tudo que os trabalhadores demandam. Necessita-se de um acordo que faça todas e todos (capital versus trabalho) felizes. Aceita-se de forma acrítica o contrato desigual entre o capital e o trabalho, culminando no consentimento do capital como única alternativa possível e legitimando a sua hegemonia.

Por isso, essa ação sindical é fundamental para a expansão territorial do capital avícola no Oeste Paranaense, e, mais ainda, é central no 
que tange à implementação dos investimentos do Estado nesse tipo de atividade do agronegócio. Não surpreende que nenhuma linha esteja presente nas publicações dos sindicatos criticando o investimento do Estado no setor. Pelo contrário, a perspectiva é apoiar o crescimento das cooperativas, podendo chegar às possíveis negociações mais "favoráveis" aos trabalhadores:

(...) então, quando o cooperado vai bem, nós temos que ir bem, a cooperativa tem que ir bem. Quando o mercado está contra, todo mundo acaba tendo que se retrair e isso têm que ter sensibilidade em entender. Por isso, que quando o momento é bom a gente luta por números cada vez maiores (...) (Representante sindical, informação verbal, grifo nosso).

O que não está explícito no interior desse fragmento de narrativa é uma afirmação anterior que pautou uma postura política assumida pelo sindicato quando da crise do mercado do frango. Houve redução dos salários dos trabalhadores pautada pelo próprio sindicato junto a sua base (para supostamente não quebrar a cooperativa), que só voltou a ascender quando o mercado "reagiu".

Isso expressa à ação sindical de braços dados com o capital porque o interesse é justamente fazer com que este último cresça, e, neste momento, conseguir ganhos salariais maiores para os trabalhadores. Por esse motivo, jamais serão estes contrários aos investimentos do Estado no setor e nunca farão críticas contundentes ao capital. São funcionais ao neodesenvolvimentismo que intensificou a expansão territorial do capital avícola nos últimos dez anos na região.

Nesse aspecto, resumem-se ao contingente e ao limite do projeto societal do capital, em colaboração com este e não o denunciando. Marx, que viu nos sindicatos uma atividade legítima e necessária, mesmo na ação contingente (sem esquecer do objetivo central que era a abolição do sistema de trabalho assalariado), já denunciava no século XIX na Inglaterra a ação sindical resumida ao fortuito e distante das lutas políticas ${ }^{11}$. Pois bem, esse ainda é um problema do movimento sindical no século XXI.

Entretanto, para adentrarmos no último ponto da nossa discussão, e não fugirmos da proposta central do presente artigo, ainda falta avaliar se tal posição política dos sindicatos gera um consenso sobre a sua base. Por sorte 
nesse aspecto se percebe mais o conflito com tais projetos políticos do que consenso.

Paralisações em determinados setores nas empresas, votações no período de negociação aprovando greve, intensa rotatividade característica principalmente do abandono do posto de trabalho a pedido dos próprios trabalhadores, parecem mostrar que os trabalhadores reagem às imposições do capital e ao projeto de colaboração com este apresentado pelos sindicatos. Isso parece se expressar nas fortes críticas que os mesmos fazem aos sindicatos identificando-os como "Sindicato das Cooperativas" e "Sindicato da Sadia". Recorremos novamente à narrativa dos trabalhadores:

(...) se acha que sindicato me ajudou? Me ajudou nada (...) aquilo ali eu acho que é $100 \%$ Sadia (...) eu acho que eles nem poderiam ser chamados de sindicato eles tinham que ser sindicato da Sadia (...) (Joana, informação verbal).

Tais argumentos são de uma trabalhadora da Sadia em Toledo (PR), mas, poderiam ser muito bem os mesmos de outros trabalhadores em frigoríficos de cooperativas. O que importa para a discussão é apontar como a própria base tem identificado os sindicatos como braços de colaboração com o capital. Por esse motivo, os trabalhadores não parecem ter reações meramente espontâneas com relação às condições de trabalho, pois, as paralisações em setores de empresa e outras ações indicam a denúncia do trabalho degradante e por vezes entram em conflito com a direção do próprio sindicato. Foi o que aconteceu no município de Cafelândia e o sindicato foi acionado para conter a paralisação dos trabalhadores.

(...) nós tivemos um momento aqui na Copacol que aconteceu assim, houve uma movimentação dos trabalhadores espontânea em que os trabalhadores se reuniram lá e fizeram uma greve entendeu? (...) o sindicato participou para tentar corrigir aquela ilegalidade porque não estava amparada dentro da lei então o sindicato não podia respaldar isso senão daí nosso sindicato teria uma responsabilização criminal e até de dano e tal que não era o sindicato que tinha promovido (...) e eu tinha ido quando houve a primeira paralisação eu fui lá falar com eles e disse assim olha vamos fazer o seguinte, vamos retornar ao trabalho e vamos fazer como se deve eu convoco uma assembléia nós extraímos uma pauta do que está acontecendo aqui que nós temos que, parece que tem muitos assuntos aqui que vocês não levaram para mim e eu não tenho o aval necessário para saber, então, retomamos o trabalho fizemos uma assembléia extraímos uma pauta e aí tentamos negociar se a cooperativa não aceitar a negociação não quiser negociar aí nós paralisamos mesmo fora da data-base porque nós temos uma cláusula na convenção coletiva que 
para qualquer momento o sindicato pode chamar para negociação e também existe a própria lei que assim autoriza que a qualquer momento pode existir a negociação coletiva e nós podemos resolver isso de uma maneira tranqüila sem ter que ir para o embate dentro da ilegalidade, não que nós não devemos ir para o embate para uma greve, mas devemos ir respaldados em toda a lei da greve em tudo dar os prazos legais tudo esse negócio pra que a gente ache um denominador comum. O pessoal falou nós não queremos, não queremos isso aí e agora nós não queremos o sindicato também deixa que nós vamos tocar isso aí, ah! beleza então eu me afastei e vim embora pra casa os caras falaram você vai embora? Ué vou embora o pessoal não quer o sindicato o sindicato vai ficar aguardando falei e saí (Representante Sindical, informação verbal).

Nesse aspecto, percebe-se que não há uma relação consensual da dominação do capital e nem mesmo das apostas políticas de colaboração da direção dos sindicatos. É muito mais o conflito que se expressa do que a aceitação pacífica e geral das políticas sindicais, o que é muito positivo.

E, no âmbito mais geral, me parece ser desse descontentamento expresso nas pequenas paralisações, por exemplo - que a partir principalmente de 2005 surge outra entidade na região que tem tido destaque na denúncia central das doenças laborais sofridas pelos trabalhadores, a Associação dos Portadores de Lesões Por Esforços Repetitivos ${ }^{12}$ (AP-LER).

Não há espaço nesse artigo para avançar nessa discussão, mas é importantíssimo apontá-la, para demonstrar que não há consenso com as práticas sindicais colaboracionistas com o capital. E, não devemos tratá-las como resistências insignificantes, ao contrário, elas parecem nos mostrar que há um descontentamento por parte dos trabalhadores com o capital e mesmo com as entidades que formalmente os representam. Elas são potenciais para a construção da resistência coletiva que podem animar enquanto projeto de futuro para a emancipação das amarras do capital e mesmo para avançar para além do projeto do agronegócio estimulado pelo Estado neodesenvolvimentista na região que tem através do tripé Estado-capital-sindicatos, mantido sua hegemonia garantindo a expansão territorial. 


\section{CONSIDERAÇÕES FINAIS}

Assim, capital, sindicatos e Estado caminham juntos para a manutenção da dominação capitalista no Oeste Paranaense. A expansão territorial do capital avícola na região intensificada pela inserção massiva do Estado neodesenvolvimentista no financiamento de investimentos, e pela ação sindical que apóia o crescimento e expansão do agronegócio na região buscando apenas maiores ganhos salariais em períodos de crescimento da atividade econômica, consolidam a hegemonia do projeto do capital.

Nesse sentido, é o Estado "pós-neoliberal" quem têm estimulado o poderio da elite agrário-exportadora de carnes na região. Não está em questão nenhuma mudança na estrutura do poderio local, ao contrário, o neodesenvolvimentismo tratou de incentivar a dominação econômica do agronegócio contribuindo para a sua hegemonia no território.

Portanto, o neodesenvolvimentismo não é alternativa para os trabalhadores. Podemos até perceber avanços nas políticas sociais, mas, elas não ultrapassam a barreira do assistencialismo e não incomodam a burguesia nacional. Logo é um exagero considerar que o neodesenvolvimentismo do PT no Brasil caracteriza-se como um governo de resistência ao neoliberalismo. Isso porque, mesmo os programas sociais recebem valores muito menores para sua manutenção do que os destinados ao capital e ainda não houve nenhuma reforma efetiva do sistema político ou uma reforma tributária (taxando maiores impostos para os mais ricos e taxação do capital parasitárioespeculativo) e nem mesmo foi proposta uma auditoria cidadã da dívida pública que abocanha quase a metade do orçamento público da união para o pagamento dos juros e amortizações o que compromete o investimentos na questão social.

Contudo, estamos distantes mesmo das reformas estruturais que poderiam aborrecer a burguesia nacional. Então não há o que se falar em rupturas radicais com o neoliberalismo, o neodesenvolvimentismo parece ser somente mais uma possibilidade da acumulação capitalista que incentiva os setores mais retrógrados da economia.

Nesse aspecto, essa política econômica estimula atividades como os frigoríficos responsáveis por inúmeras doenças laborais e por déficits 
significativos aos cofres públicos da Previdência Social. Eis o neodesenvolvimentismo tal como ele é: uma política que corresponde aos interesses da burguesia distribuindo pequeníssimas partes aos trabalhadores pobres via políticas sociais. Um reformismo sem reformas estruturais que legitima a expansão territorial do capital no território. Uma armadilha para os trabalhadores!

\section{REFERÊNCIAS BIBLIOGRÁFICAS}

ALVES, Giovanni. Os limites do neodesenvolvimentismo. Disponível em: $<$ http://blogdaboitempo.com.br/2013/10/22/os-limites-do-

neodesenvolvimentismo/>. Acesso em: 24 abr. 2014.

BOITO JUNIOR, Armando. Governos Lula: a nova burguesia nacional no poder. In: BOITO JUNIOR, Armando e GALVÃO, Andréia (orgs.) Política e classes sociais no Brasil dos anos 2000. São Paulo: Alameda, 2012, p.67104.

BOITO JUNIOR, Armando BERRINGER, Tatiana. Brasil: classes sociais, neodesenvolvimentismo e política externa nos governos Lula e Dilma. Revista de Sociologia e Política, v.21, n.47, p.31-38, set.2013.

BOSI, Antonio de Pádua. Trabalhadores e relações de trabalho na cadeia avícola no Oeste do Paraná (1970-2010). In: VIII Seminário do Trabalho. Anais... Marília: Rede de Estudos do Trabalho, 2012, p.1-13.

BRANDÃO, Carlos. Acumulação primitiva permanente e desenvolvimento capitalista no Brasil contemporâneo. In: ALMEIDA, Alfredo Wagner Berno [et al.] (orgs.) Capitalismo globalizado e recursos territoriais: fronteiras da acumulação no Brasil contemporâneo. Rio de Janeiro: Lamparina, 2010, p.3969.

MARX, Karl. Resolução da Associação Internacional dos Trabalhadores sobre os sindicatos. In: MARX, Karl; ENGELS, Friedrich. Sindicalismo: Marx e Engels. Tradução de: José Roberto Marinho. São Paulo: CHED, 1980. p.13-17. (coleção polêmicas operárias: série sindicato).

MÉSZÁROS, István. O desafio e o fardo do tempo histórico. São Paulo: Boitempo Editorial, 2007.

NOTÍCIAS DA PROCURADORIA REGIONAL DO TRABALHO DO RIO GRANDE DO SUL. Inferno Frio: a vida por trás da linha de produção dos frigoríficos. Porto Alegre: Ministério Público do Trabalho, v. 9, n.3, out-dez. 2009. 
PROCURADORIA REGIONAL DO TRABALHO DA 9a REGIÃO. Procuradoria em Foz combate irregularidades trabalhistas em cooperativa frigorífica.Informativo PRT9, Curitiba, v.10, n.23, p.7, abr 2009. Disponível em: $<$ http://www.prt9.mpt.gov.br/images/arquivos/ascom/informativos/informativo_2 3.pdf>. Acesso em: 24 abr. 2014.

Inspeção em frigorífico de Palotina encontra irregularidades. Informativo PRT9, Curitiba, v.12, n.30, p.8, nov. 2011. Disponível em: $<$ http://www.prt9.mpt.gov.br/images/arquivos/ascom/informativos/informativo_3 0.pdf>. Acesso em: 24 abr. 2014.

SADER, Emir. A construção da hegemonia pós-neoliberal. In: 10 anos de governos pós-neoliberais no Brasil: Lula e Dilma. SADER, Emir. (org.). São Paulo: Boitempo; Rio de Janeiro: FLACSO Brasil, 2013, p. 135-143.

SAMPAIO JUNIOR, Plínio de Arruda. Desenvolvimentismo e neodesenvolvimentismo: tragédia e farsa. Serviço Social \& Sociedade, n. 112, p.672-688, out./dez. 2012.

\section{SOARES, Pedro. Frigoríficos recebem $\mathbf{R} \$ 13$ bi do BNDES, mas enfrentam problemas. Disponível em: $<$ http://www1.folha.uol.com.br/mercado/2014/01/1399692-frigorificos-recebem- r-13-bi-do-bndes-mas-enfrentam-problemas.shtml>. Acesso em: 24 abr. 2014.}

VARUSSA, Rinaldo. Sindicalismo e trabalhadores em cooperativas no Oeste do Paraná (décadas de 1990 e 2000). Mundos do Trabalho, v. 4, n.7, 2012.

\footnotetext{
${ }^{1}$ Doutorando em Geografia pela Universidade Estadual Paulista (UNESP) campus de Presidente Prudente. Membro do Centro de Estudos de Geografia do Trabalho (CEGeT). Bolsista do Conselho Nacional de Desenvolvimento Científico e Tecnológico (CNPQ). Email: fernandomheck@gmail.com.

${ }^{2}$ Emir Sader, por exemplo, expõe essa visão de que a reprimarização da economia, a desindustrialização, entre outros, são problemas herdados da década neoliberal, pressupondo que o petismo tivesse por objetivo romper com tais retrocessos. Nas suas palavras: "Esses governos de resistência se construíram como respostas anticíclicas às tendências regressivas do centro do capitalismo. Conseguiram resistir à recessão, mas tiveram de se adaptar aos retrocessos impostos pelo neoliberalismo: a desindustrialização, o protagonismo de exportador primário, uma sociedade fragmentada, as ideologias consumistas" (p.141).

${ }^{3}$ Usamos essa terminologia através da discussão apresentada por Giovanni Alves citando o livro de André Singer que trata sobre o fenômeno chamado de "lulismo".

${ }^{4}$ Vejamos alguns exemplos: A Cooperativa Agrícola Mista Rondon (Copagril) recebeu 20 milhões em 2004 para implantação do abatedouro de aves; a Cooperativa Agroindustrial Lar (LAR) recebeu mais 12,6 milhões no mesmo ano para unidades de armazenagem de grãos e unidade de produção de leitões e, mais 15,6 milhões para implantar granjas de matrizes em 2006; a C-Vale Cooperativa Agrindustrial recebeu 26 milhões para a instalação de uma unidade de produtos industrializados da carne de frango em 2005; a Cooperativa Agroindustrial Consolata (Copacol) recebeu 20 milhões para expansão da capacidade de armazenagem e secagem de grãos e de seus
} 
matrizeiros avícolas, bem como, na ampliação da fábrica de rações e frigorífico no ano de 2004 e, mais 28,6 milhões para ampliar a capacidade de abate do frigorífico de aves em 2007; a Cooperativa Agropecuária Cascavel Ltda (Coopavel) recebeu 20 milhões para aumentar a capacidade de abate de frangos e construir mais dois frigoríficos em 2004. Informações obtidas no sítio do BNDES.

${ }^{5}$ Eis os números: 1994 - 648 empregos e 2011 - 26.244 empregos.

6 Todos os nomes de trabalhadores citados são fictícios para preservar suas identidades.

${ }^{7}$ A ficha é o pedido para se afastar temporariamente do trabalho por algum motivo. $\mathrm{Na}$ maioria dos casos se refere às dores sentidas pelos trabalhadores.

${ }^{8}$ Encostar é a palavra utilizada pelos trabalhadores para caracterizar o afastamento do trabalho.

${ }_{9}^{9}$ As informações apontadas pelo MPT são referentes às inspeções ocorridas nos frigoríficos da LAR sob responsabilidade do Procurador Enoque Ribeiro e na C-Vale pelas procuradoras Sueli Bessa e Patrícia Patruni.

${ }^{10}$ Cf. Ação Civil Pública ํo 01428-2010-068-09-00-5.

11 Cf. Marx (1980), ver o texto: "Resolução da Associação Internacional dos Trabalhadores sobre os Sindicatos" (p.13-15).

12 Inclusive é fruto das denúncias dessa associação que a Sadia está sendo investigada no que tange às condições de trabalho no município de Toledo que culminou na abertura de Procedimento Investigatório e posteriormente na Ação Civil Pública que deve ter seu desfecho no final de abril de 2014.

RECEBIDO EM: outubro/2014

APROVADO EM: novembro /2014 